\title{
Konvencionalne cigarete vs. alternativni uređaji - štetnost po zdravlje čovjeka i ekosustav
}

\author{
D. Kučić Grgić, ${ }^{a *}$ I. Bićanić, N. Čavarović, ${ }^{a}$ \\ P. Pohanića i V. Ocelić Bulatovićb \\ a Fakultet kemijskog inženjerstva i tehnologije, Sveučilište u Zagrebu, Hrvatska \\ b Metalurški fakultet, Sveučilište u Zagrebu, Hrvatska
}

Ovo djelo je dano na korištenje pod Creative Commons Attribution 4.0 International License

\begin{abstract}
Sažetak nego kod konvencionalnih cigareta.

\section{Ključne riječi}

Duhanski dim, ENDS, HNBT, aerosol, štetni učinci, zdravlje čovjeka i ekosustav
\end{abstract}

Duhanski dim prvi je sprječiv uzrok smrti, a pušenje je danas sve manje prihvatljivo u mnogim društvenim segmentima. Radi vlastitog opstanka na tržištu duhanska industrija posljednjih desetak godina razvija alternativne proizvode - ENDS (engl. electrical nicotine delivery system) i HNBT (engl. heat-not-burn), kako bi ponudila manje štetnu opciju potrošačima. Proizvođači e-cigareta pozivaju se na deklaraciju GRAS, koja se odnosi isključivo na konzumiranje ingestijom, dok je već i udisanje samog aerosola, koji nastaje kod oba navedena proizvoda, štetno. E-cigarete stvaraju aerosol zagrijavanjem e-tekućine, dok se HNBT uređaji temelje na zagrijavanju komprimiranog lišća duhana, čime nastaju štetni spojevi iako u znatno manjim koncentracijama

\section{Uvod}

Smatra se da duhanski dim, nastao izgaranjem konvencionalne cigarete, godišnje usmrti oko 6 milijuna ljudi, odnosno svakih šest sekundi od posljedica izloženosti duhanskom dimu u svijetu umre jedna osoba. Naime, smatra se kako je 2016. godine u Republici Hrvatskoj, 9795 smrtnih slučajeva bilo povezano s posljedicama izloženosti duhanskom dimu. ${ }^{1}$ Može se reći da je svaka peta smrt u Republici Hrvatskoj povezana s pušenjem, ${ }^{1}$ a Svjetska zdravstvena organizacija (engl. World Health Organisation - WHO) ističe kako je pušenje i dalje glavni, sprječivi uzrok smrti u svijetu. ${ }^{2}$ Duhanski dim postao je nepoželjna društvena navika i više nije prihvatljiv u mnogim društvenim okruženjima. ${ }^{3}$ Duhanski dim štetno utječe na zdravlje čovjeka i ekosustav, odnosno uzrokuje kardiovaskularne bolesti, uključujući moždani udar, rak i kronične bolesti dišnog sustava, a otkriveni su i štetni učinci opušaka na komarce i morske puževe. ${ }^{3}$ Nikotin utječe na reprodukciju, razmnožavanje stanica, oksidativni stres, mutacije DNA kao i apoptozu. Upravo zbog toga, kako bi opstala na tržištu, duhanska industrija je krenula ulagati u razvoj novih, alternativnih proizvoda. ${ }^{4}$ Prvi široko rasprostranjeni alternativni proizvodi na tržištu bili su električne cigarete tzv. e-cigarete ili ENDS (engl. electrical nicotine delivery system), a nakon toga pojavili su se heat-not-burn (HNBT) proizvodi. ${ }^{5}$ Navedeni proizvodi smatraju se "zdravijom" alternativom konvencionalnoj duhanskoj cigareti. Međutim, ENDS i HNBT podvrgnute su temperaturama do $350{ }^{\circ} \mathrm{C}$, što je dovoljno visoko da izazove kemijske reakcije između različitih sastojaka te rezultira stvaranjem produkata razgradnje koji štetno djeluju na organizam. ${ }^{5}$

\footnotetext{
*Autor za dopisivanje: doc. dr. sc. Dajana Kučić Grgić e-pošta: dkucic@fkit.hr
}

\section{Teorijski dio}

\subsection{Duhanski dim konvencionalnih cigareta}

Duhanski dim složena je smjesa plinova i čvrstih čestica koja sadrži preko 7000 spojeva, od kojih 93 spoja Agencija za hranu i lijekove Sjedinjenih Američkih Država (engl. Food and Drug Administration - FDA) smatra štetnim ili potencijalno štetnim za zdravlje. ${ }^{6}$ On nastaje izgaranjem duhana zajedno s različitim aditivima i papirom na vrlo visokoj temperaturi, koja može doseći $900{ }^{\circ} \mathrm{C} .{ }^{7}$ Naime, u usitnjenu duhansku smjesu dodaju se još humektanti, primjerice propilen glikol koji održava vlažnost duhana ${ }^{8}$ u svrhu produljenja roka trajanja proizvoda, ${ }^{9}$ kemikalije poput amonijaka, zatim sredstva za poboljšanje okusa te šećeri kako bi nastali dim postao lakši za udisanje. ${ }^{9}$

lako jedna cigareta obično teži manje od $1 \mathrm{~g}$, tijekom pušenja ona može emitirati između 7 mg i 23 mg lebdećih Čestica, $\mathrm{PM}_{2,5}$, ovisno o uvjetima pušenja i vrsti marke cigarete, a prosječan promjer lebdećih čestica iznosi između $0,1 \mu \mathrm{m}$ i $0,2 \mu \mathrm{m}$, te se one klasificiraju kao ultrafine čestice koje prodiru duboko u pluća i uzrokuju ozbiljno oštećenje alveola i ireverzibilne ozljede pluća. ${ }^{10}$ Zanimljivo je kako duhanski dim sadrži više lebdećih čestica od dizelskog motora u praznom hodu. ${ }^{11}$

Duhanski dim se dijeli na glavni strujni dim, bočni dim i dim koji pušač izdiše nakon inhalacije glavnog strujnog dima koji nastaje potpunim izgaranjem komponenata cigarete pri temperaturama do $900{ }^{\circ} \mathrm{C}$, a inhalira ga pušač. ${ }^{12}$ Aktivno pušenje čimbenik je rizika za kardiovaskularne bolesti, moždani udar, rak i kronične bolesti dišnog sustava te čini veliku globalnu prijetnju javnom zdravlju. ${ }^{13}$ Također, istraživanja su pokazala kako je pušenje povezano s povećanim rizikom od prijeloma, povećanom bolesti zglobova i rizikom od neprihvaćanja implantanata. ${ }^{14}$ Pronađeni su štetni učinci na mišiće, tetive, hrskavice i ligamente. ${ }^{14} \mathrm{Pu}-$ 
šači imaju 30 - $40 \%$ veći rizik za razvoj dijabetesa tipa $2^{15}$ te dvostruko češću učestalost pojave depresije u usporedbi s nepušačima, a usporednim konzumiranjem duhana i alkohola rizik od raka grkljana povećava se za $75 \%{ }^{8}$

Bočni dim, koji izlazi s bočnih strana duhanskog proizvoda, ${ }^{15}$ čini $85 \%$ dima u zatvorenoj prostoriji, ${ }^{9}$ a nastaje prilikom izgaranja cigarete sa žarnog vrha, pri temperaturi od $600{ }^{\circ} \mathrm{C}$ te se zbog nepotpunog izgaranja supstancija iz duhana, papira i aditiva razvija $\mathrm{N}$-nitrozamin koncentracije 10 do 100 puta veće u usporedbi s dimom koji izdiše pušač. ${ }^{12}$ Bočni dim sadrži veće koncentracije policikličkih aromatskih ugljikovodika (PAH), nitrozamina te ugljikova monoksida. Upravo zbog toga bočni dim uzrokuje velik broj kardiovaskularnih bolesti među nepušačima kao i rak pluća. Izloženost bočnom dimu povećava rizik od moždanog udara ${ }^{8}$ i povećava tendenciju stvaranja krvnih ugruša$\mathrm{ka}^{7}$ dok kod djece može uzrokovati upale uha, napadaje astme, bronhitis, upale pluća te respiratorne simptome poput kašljanja i kihanja. ${ }^{8}$ Dim cigareta ostaje u zraku prostorije sljedećih osam sati. ${ }^{12}$

Važno je napomenuti i postojanje tzv. thirdhand smoke (THS). To je duhanski dim koji se zadržavana u unutarnjim površinama te se ugrađuje u materijale zidova, namještaja, odjeće pa čak i igračaka nakon prestanka aktivnog pušenja i može se ponovno emitirati u okolinu. ${ }^{16}$ Primjerice, otpušteni nikotin iz pojedinih materijala može reagirati s ozonom i dušičnim kiselinama prisutnim u zatvorenom prostoru te kemijskim reakcijama ${ }^{8}$ nastaje karcinogeni nitrozamin. ${ }^{17}$ Istraživanje tvrtke Philip Morris International (PMI) pokazalo je postojanost visokih koncentracija nikotina i 4-(metilnitrozamino)-1-(3-piridil)-1-butanona, u kontroliranom okruženju više od 100 dana nakon prestanka pušenja, dok su ispitivanja in vitro i in vivo pokazala kako izlaganje THS-u uzrokuje oštećenje DNA te usporava zacjeljivanje rana. ${ }^{16}$

Osim što je duhanski dim opasan za ljudsko zdravlje, odbačeni opušci opasnost su za ekosustav. Istraživanja na komarcima izleglim u vodenim sredinama koje sadrže odbačene opuške cigareta pokazala su kako komarci imaju veću stopu smrtnosti tijekom razvojne faze, ali i kraći životni vijek. ${ }^{18}$ Također, opušci uzrokuju promjene u ponašanju i mortalitet morskih puževa. ${ }^{18}$

\subsection{Utjecaj nikotina na organizam}

Nikotin je jedan od alkaloida u duhanu te je primarna psihoaktivna tvar u cigaretama koja izaziva ovisnost. ${ }^{9}$ Nikotin se nakon inhalacije vrlo brzo apsorbira u plućnu cirkulaciju ${ }^{13}$ i dospijeva u mozak nakon 10 sekundi. Tamo se veže na acetilkolinske receptore i uzrokuje oslobađanje dopamina ${ }^{19}$ koji je zadužen za osjećaj zadovoljstva. ${ }^{20}$ Također, nikotin smanjuje stres i tjeskobu, poboljšava koncentraciju i vrijeme reakcije. Međutim, kronična upotreba nikotina može izazvati toleranciju ovisno o uzetoj dozi kao i o izloženosti. ${ }^{21}$ Nakon nekog vremena acetilkolinski receptori postaju manje osjetljivi na nikotin te su potrebne znatno veće koncentracije apsorbiranog nikotina za postizanje jednakog učinka. Prestanak pušenja uzrokuje razdražljivost, depresivno raspoloženje, nemir, anksioznost, povećanu glad i žudnju za duhanom koja se može ublažiti terapijskom zamjenom nikotina. ${ }^{22,23}$
IARC (engl. International Agency for Research on Cancer) ne klasificira nikotin u karcinogene tvari, no prema brojnim istraživanjima na ljudima i životinjama on predstavlja nekoliko opasnosti po zdravlje. Povećava rizik od kardiovaskularnih, respiratornih i gastrointestinalnih poremećaja, uzrokuje smanjen imunološki odgovor i ima negativan učinak na reproduktivno zdravlje, ${ }^{24}$ lako prelazi posteljicu i ulazi u fetalnu krv i plodnu vodu, ${ }^{19}$ utječe na razmnožavanje stanica, oksidativni stres, mutacije DNA kao i apoptozu, ${ }^{24}$ odnosno uzrokuje pokretanje vlastite smrti stanica kao sastavni dio fizioloških procesa. ${ }^{25}$ Utječe i na širenje tumorskih stanica te uzrokuje otpornost na kemoterapiju i radioterapiju. ${ }^{24}$ Opaženo je kako upotreba nikotina pokazuje određenu toleranciju na analgetike te da askorbinska kiselina reagira s nikotinom ${ }^{23}$ i dodatnim unošenjem askorbinske kiseline smanjuje se apsorpcija nikotina u krv. ${ }^{26}$

\subsection{Električne cigarete (e-cigarete, ENDS)}

Kao "zdrava" alternativa konvencionalnoj duhanskoj cigareti, na tržištu su se 2006. godine pojavile ENDS te su od tada sve popularnije. Samo na američkom tržištu postoji 250 proizvođača ENDS-a i oko 8000 različitih okusa e-tekućina, ${ }^{27}$ a procjenjuje se da je 2012. godine prodano 3,5 milijuna uređaja. ${ }^{28} \mathrm{U}$ masovnim se medijima sugerira da pomažu pušačima dugotrajno prestati pušiti ili pak smanjiti potrošnju cigareta. Međutim, ti proizvodi se propagiraju kao bezopasni, dok raznolika ponuda okusa na tržištu privlači mlade ljude i to često nepušače. ${ }^{29}$

ENDS se sastoji od plastične cijevi, električnog grijača i spremnika za e-tekućinu, koja je najčešće otopina čistog nikotina u propilen glikolu i biljnom glicerinu s dodatkom aroma. ${ }^{30,31}$ Zagrijavanjem e-tekućine nastaje aerosol nalik dimu, koji se udiše. Propilen glikol i glicerin služe kao humektanti, aerosolizirajući nikotin i arome pri zagrijavanju. ${ }^{27,28} \mathrm{Na}$ tržištu su dostupni različiti okusi s atraktivnim nazivima poput Muffin, Cotton Candy, Milk and Honey, Apple Pie, Melon Mania, Cheese Cake, Chocolate, Coconut i dr., a kemijski sastav pojedinog okusa varira od proizvođača do proizvođača. Velik dio aroma koje se upotrebljavaju u tim proizvodima FDA je deklarirala kao sigurne za ingestiju, odnosno probavni sustav te su svrstani u skupinu GRAS (engl. Generally Recognized as Safe) spojeva. ${ }^{27,31}$ Unatoč tome što se takva deklaracija ne odnosi na konzumaciju inhalacijom, brojni proizvođači jamče bezopasnost tih proizvoda pozivajući se na GRAS oznaku. O inhalacijskoj toksičnosti e-tekućina i aerosola ne zna se mnogo. Ipak, sve je više dokaza u prilog tome da konzumacija e-cigareta znatno šteti plućima i dišnome sustavu. ${ }^{31}$

Spojevi koji se trenutačno najviše primjenjuju kao poboljšivači okusa su mentol, diacetil i 2,3-pentandion. Diacetil se prirodno nalazi u nekim namirnicama ili se dodaje u hranu i piće (maslac, karamelu, kakao, mliječne proizvode, alkoholna pića), jer daje karakterističnu aromu maslaca. Siguran je za konzumaciju u gastrointestinalnom traktu, no njegovo udisanje manifestira se padom respiratorne funkcije, a kronična izloženost često rezultira razvojem poremećaja dišnog sustava pod nazivom bronchiolitis obliterans (engl. popcorn disease). Mentol svojim farmakološkim djelovanjem ublažava iritaciju koju uzrokuje nikotin te pobuđuje osjetilne učinke, čime potiče dublje udisanje aerosola e-ci- 
garete povećavajući tako apsorpciju i učinak nikotina. ${ }^{27}$ ENDS mogu i ne moraju sadržavati nikotin (raspon koncentracija je $\left.0-36 \mathrm{mg} \mathrm{ml}^{-1}\right)^{27}$ a utvrđeno je da su podatci navedeni na pakiranju e-tekućine često netočni pa e-tekućina koja prema oznaci ne sadrži nikotin, ipak sadrži, ${ }^{27,30}$ ili pak nekoliko pakiranja e-tekućina s naznačenim istim koncentracijama sadrže različite koncentracije nikotina. ${ }^{32}$

ENDS se smatraju sigurnijom alternativom zbog jednostavnog sastava i nesagorijevanja, no e-tekućine podvrgnute su temperaturama do $350{ }^{\circ} \mathrm{C}$, što je dovoljno visoko da izazove kemijske reakcije između različitih sastojaka te rezultira stvaranjem produkata razgradnje. ${ }^{30}$ Osim nikotina, udisanjem para ENDS-a udišu se i produkti zagrijavanja propilen glikola i glicerina odnosno aldehidi poput formaldehida, acetaldehida, propanala i akroleina. Formaldehid je klasificiran kao karcinogen, a akrolein može doprinijeti razvoju kardiovaskularnih bolesti. ${ }^{30}$ Ostale komponente mogu biti i o-metil-benzaldehid, karcinogeni nitrozamini, terpenski spojevi poput limonina te čestice teških metala i silikata ( $>1 \mu \mathrm{m})$. Druga pak istraživanja navode da su razine nastalih aldehida vrlo niske, a visoke razine formaldehida mogu biti eventualno posljedica pregrijavanja zaostale tekućine u spremniku pri visokom naponu, što korisnici ne prakticiraju jer stvara neugodan okus. ${ }^{29}$ Istraživanjem utjecaja napona baterije na sastav reakcijskih produkata, kod baterije od $3 \mathrm{~V}$ nisu nađeni reakcijski produkti, dok je pri $5 \mathrm{~V}$ nađen hidrokisaceton kao produkt zagrijavanja propilen glikola te je utvrđena citotoksičnost u 80 \% uzoraka. ${ }^{33}$ Smjesa propilen glikola i glicerina ne ukazuje na toksične učinke prilikom ispitivanja subkronične toksičnosti na miševima, a dodatkom nikotina pokazuje uobičajene učinke nikotina. ${ }^{34}$ Aktualna istraživanja ukazuju na povezanost ENDS-a, odnosno e-tekućina s upalnim učincima na plućnom tkivu. Bez obzira na spojeve, već i sama aerosolizacija do ultrafinih čestica koje mogu dosegnuti distalna i periferalna područja pluća opasna je za čovjeka. ${ }^{27}$ Aerosol e-tekućina potiče proizvodnju upalnih proteina in vitro, u stanicama ljudskog epitela iz dišnih puteva te in vivo u dišnim putevima štakora. ${ }^{29}$ Uzročnik je pojave oksidativnog stresa, imunogenih učinaka te oštećenja DNA u stanicama pluća, 27,29,31 a uzrokuje i trošenje glutationa, glavnog antioksidansa u tijelu. ${ }^{29}$

Postoji i zabrinutost u svezi s čistoćom primijenjenih kemikalija te općim nedostatkom nadzora proizvodnje i marketinga tih proizvoda. Naime, iako su na tržištu od 2006. godine, do 2016. ENDS su se prodavale bez ikakvog nadzora. ${ }^{27}$ Zbog nedostatka podataka o sigurnosti tih proizvoda i utjecaja na zdravlje FIRS (engl. Forum of International Respiratory Societies) smatra kako bi se distribucija i potrošnja ENDS-a trebala ograničiti ili zabraniti. ${ }^{29}$

\subsection{Uređaji za zagrijavanje duhana (heat - not - burn tobacco - HNBT)}

Duhanska industrija usmjerena je na pronalaženje alternativnih proizvoda koji imaju niže razine štetnih i potencijalno štetnih spojeva u odnosu na konvencionalne cigarete. Usmjereni su na smanjenje štetnog učinka na zdravlje promjenom načina zagrijavanja duhana i poticanjem javnosti na prihvaćanje HNBT proizvoda. ${ }^{35-37}$
PMI je stvorio HNBT pod nazivom I-Quit-Ordinary-Smoking (IQOS), koji je inicijalno pokrenut 2014. u Nagoyi, Japanu i Milanu. Osim toga, British American Tobacco (BAT) stvorio je HNBT pod nazivom "glo", koji je prvobitno pokrenut 2016. u Sendaiju, Japan.

Japan Tobacco (JT) naknadno je ažurirao 2016. hibridni proizvod HNBT-a i ENDS pod nazivom "Ploom TECH", koji je prvobitno pokrenut 2013. u Fukuoki, Japan. Glicerin, propilen glikol i vodena para prolaze kroz duhansku kapsulu pri maksimalnoj temperaturi od $300{ }^{\circ} \mathrm{C} .{ }^{37,38}$

IQOS i "glo" rade na principu zagrijavanja duhana, a ne na njegovom sagorijevanju u svrhu stvaranja pare infuzirane nikotinom. Upotrebom Ploom TECH-a udiše se dim koji sadrži nikotin, a grijanjem e-tekućine nastaje aerosol koji sadrži propilen glikol i glicerol koji prolazi kroz kapsulu granuliranog lišća duhana. Trenutačno se HNBT proizvodi distribuiraju širom svijeta. Smatra se da HNBT oslobađaju manje kemijskih spojeva jer nema izgaranja duhana, što dovodi do smanjenja ili uklanjanja spojeva koji se proizvode samo pri temperaturama izgaranja. HNBT dosežu temperature $300-350{ }^{\circ} \mathrm{C}$, za razliku od temperaturne zone izgaranja $700-900{ }^{\circ} \mathrm{C}$ od konvencionalne cigarete. ${ }^{39}$

HNBT se čini manje štetnim od konvencionalnih cigareta u smislu zdravstvenih učinaka. Međutim, dostupni su ograničeni analitički podatci koji potvrđuju tu tvrdnju. ${ }^{40}$ HNBT, u principu, ne proizvode dim kao konvencionalne cigarete zbog nedostatka potpunog izgaranja. Međutim, oni postižu dovoljno visoke temperature da bi došlo do piroliznih reakcija $\left(400-600{ }^{\circ} \mathrm{C}\right)$. Sastavni dijelovi glavnog strujanja dima iz sustava grijanja duhana manji su u usporedbi s konvencionalnim cigaretama. Međutim, štetni spojevi za ljudsko zdravlje još uvijek su prisutni u dimu koji proizvodi IQOS. Nadalje, sveprisutni sastojci konvencionalnog cigaretnog dima kao što su katran, nikotin, karbonilni spojevi (tj. formaldehid, akrolein, acetaldehid) i nitrozamini prisutni su u dimu iz sustava grijanja duhana IQOS-a. Sustavi grijanja duhana mogu sniziti te toksične sastojke konvencionalnog glavnog dima, no i dalje postoje u različitim koncentracijama i/ili mogu imati neke dodatne hlapljive tvari, što čini značajan rizik za zdravlje korisnika. Istraživanja su također pokazala da aromatizirani IQOS dim kao što je mentol sadrži još veće koncentracije tih štetnih sastojaka. Istraživanja su dodatno pokazala da udisani dio IQOS dima sadrži nikotin, acetaldehid i druge hlapljive organske spojeve. ${ }^{41}$ To povećava rizik od onečišćenja zatvorenih prostora, kao što su restorani i radna mjesta, čime se populacija nepušača izlaže štetnim tvarima pasivnim načinom pušenja. Unatoč tome oko 6,6 milijuna potrošača već je odlučilo prijeći s cigareta na sustav za grijanje duhana IQOS. ${ }^{42}$

\subsection{Usporedba konvencionalne cigarete vs. ENDS vs. HNBT}

Brojna su istraživanja provedena za usporedbu štetnosti opisanih proizvoda prilikom konzumacije aktivnim ili pasivnim putem, prema vrsti i količini spojeva te prema česticama koje se emitiraju. U tablici 1 prikazani su rezultati ispitivanja sastava zraka, odnosno koncentracije čestica u nekoliko automobila različitih veličina nakon konzumaci- 
je konvencionalnih duhanskih cigareta, ENDS-a i IQOS-a (HNBT tip uređaja).

Takvo je istraživanje vrlo praktično, s obzirom na broj pušača koji puše u automobilima kao i na mali volumen automobila u odnosu na druge zatvorene ili otvorene prostore, zbog čega se može očekivati da su koncentracije čestica i spojeva još više.

U sva tri slučaja kvaliteta zraka u automobilu narušena je emisijama finih i ultrafinih čestica te organskih spojeva. Konzumacijom IQOS-a znatno je porasla razina čestica $25-300 \mathrm{~nm}$ u svim ispitanim automobilima, no trenutačno nema dovoljno znanstvenih podataka o utjecaju navedenoga na čovjeka. IQOS i ENDS uzrokovali su porast razine nikotina, što ukazuje na mogućnost akumulacije u organizmu pasivnih pušača. Dok potencijalni učinak pasivne izloženosti "dimu" IQOS-a nije u potpunosti poznat, brojna istraživanja ukazuju na negativne učinke redovite pasivne izloženosti parama ENDS-a. 27,29,31 Dugoročno izlaganje ultrafinim kapljicama propilen glikola može povećati rizik od razvoja astme kod djece i adolescenata, negativno utjecati na obnavljanje oštećenog tkiva pluća nakon infekcije ili kronične upale. ${ }^{43}$

Istraživanja ${ }^{35-37}$ su pokazala kako HNBT proizvodi emitiraju veće količine glicerola i propilen glikola od konvencionalnih cigareta koje sadrže znatno više nikotina i acetaldehida ${ }^{44}$ (slika 1).

U radu Protano $i$ sur. ${ }^{45}$ provedena su mjerenja aerosola $u$ modalnoj prostoriji u kojoj su pušene konvencionalne i ručno motane cigarete, cigara i lula te ENDS-a i IQOS-a. Podatci dobiveni mjerenjem primijenjeni su za procjenu doze deponiranih čestica u respiratornom sustavu pojedinaca od 3 mjeseca do 21 godine starosti. Tablica 2 prikazu-

Tablica 1 - Broj čestica po jedinici volumena u automobilima različitih veličina (1.a i 1.b = veći automobili, 2.a = srednji automobil, 3.a i 3.b = manji automobili) nakon konzumacije različitih nikotinskih proizvoda u unutrašnjosti automobila ${ }^{43}$

Table 1 - Number of particles per unit of volume in cars of different sizes (1.a and 1.b = larger cars, 2.a = midsize cars, $3 . a$ and $3 . b=$ smaller cars) after consumption of various nicotine products in the interior of the car ${ }^{43}$

\begin{tabular}{|c|c|c|c|}
\hline \multirow[b]{2}{*}{ Automobil } & \multicolumn{3}{|c|}{ Broj čestica $/ \mathrm{cm}^{3}$ automobila } \\
\hline & $\begin{array}{l}\text { čestice promjera veličine } \\
\qquad 25-300 \mathrm{~nm}\end{array}$ & $\begin{array}{l}\text { čestice promjera veličine } \\
300 \mathrm{~nm} \text { do }>200 \mu \mathrm{m}\end{array}$ & $\begin{array}{c}\text { čestice promjera veličine } \\
0,1-0,2 \mu \mathrm{m}\left(\mathrm{PM}_{2,5}\right)\end{array}$ \\
\hline \multicolumn{4}{|c|}{ 1.a Škoda Octavia } \\
\hline kontrola (bez pušenja) & 10,491 & 20 & 6 \\
\hline IQOS & 16,726 & 23 & 6 \\
\hline ENDS & 53,579 & 2145 & 490 \\
\hline konvencionalna cigareta & 181,487 & 3420 & 759 \\
\hline \multicolumn{4}{|c|}{ 1.b Volvo $\mathrm{S}$} \\
\hline kontrola (bez pušenja) & 20,231 & 41 & 10 \\
\hline IQOS & 22,152 & 90 & 19 \\
\hline ENDS & 14,209 & 659 & 170 \\
\hline konvencionalna cigareta & 191,173 & 4168 & 895 \\
\hline \multicolumn{4}{|c|}{ 2.a VW Golf (2006) } \\
\hline kontrola (bez pušenja) & 20,675 & 22 & 7 \\
\hline IQOS & 29,044 & 40 & 11 \\
\hline ENDS & 33,014 & 1362 & 262 \\
\hline konvencionalna cigareta & 236,167 & 2863 & 594 \\
\hline \multicolumn{4}{|c|}{ 3.a Smart FortFour } \\
\hline kontrola (bez pušenja) & 17,716 & 14 & 4 \\
\hline IQOS & 25,616 & 21 & 5 \\
\hline ENDS & 13,543 & 90 & 18 \\
\hline konvencionalna cigareta & 107,534 & 940 & 189 \\
\hline \multicolumn{4}{|c|}{ 3.b Fiat Punto } \\
\hline kontrola (bez pušenja) & 18,626 & 19 & 9 \\
\hline IQOS & 28,827 & 10 & 4 \\
\hline ENDS & 19,901 & 28 & 8 \\
\hline konvencionalna cigareta & 24,319 & 288 & 64 \\
\hline
\end{tabular}




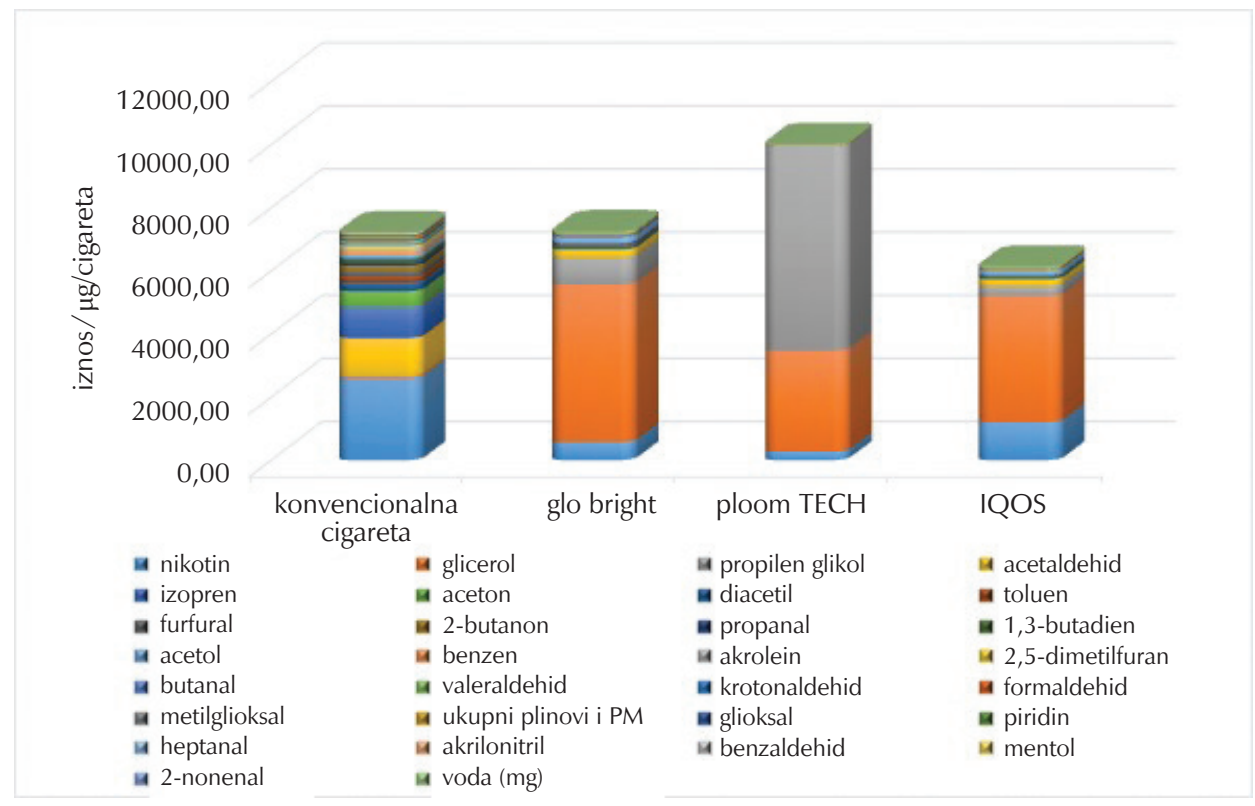

Slika 1 - Usporedba nastalih kemijskih spojeva iz konvencionalnih cigareta i HNBT-proizvoda (glo, ploom TECH, IQOS) ${ }^{44}$

Fig. 1 - Comparison of the resulting chemical compounds from conventional cigarettes and HNBT products (glo bright, ploom TECH, IQOS) ${ }^{44}$

Tablica 2 - Regionalne kumulativne doze izražene u postotcima ukupnih kumulativnih doza $\left(\mathrm{CD}_{\text {Tot }}\right)$, kao funkcije starosti izloženih osoba, za glavu (H), traheje-bronhije (TB) i alveole (A). $\Delta t_{1}, \Delta t_{2}, \Delta t_{3}$ predstavljaju tri intervala od $1 \mathrm{~h}$ tijekom kojih je provedena jedna sesija pušenja ${ }^{45}$

Table 2 - Regional cumulative doses expressed as \% of total cumulative dose $\left(\mathrm{CD}_{\text {Tot }}\right)$ as functions of the age of exposed individuals for head $(\mathrm{H})$, trachea-bronchial (TB), and alveolar (A). $\Delta t_{1}, \Delta t_{2}, \Delta t_{3}$ represent three $1 \mathrm{~h}$ intervals during which a single smoking session was carried out ${ }^{45}$

\begin{tabular}{|c|c|c|c|c|c|c|c|c|c|c|}
\hline \multirow{2}{*}{$\begin{array}{c}\text { Starost } \\
\text { izložene osobe }\end{array}$} & \multirow{2}{*}{ Interval } & \multicolumn{3}{|c|}{ ENDS } & \multicolumn{3}{|c|}{ IQOS } & \multicolumn{3}{|c|}{ Konvencionalne cigarete } \\
\hline & & $\mathrm{H} \%$ & TB \% & $\mathrm{A} \%$ & $\mathrm{H} \%$ & TB $\%$ & A \% & $\mathrm{H} \%$ & TB \% & A \% \\
\hline \multirow{3}{*}{$3 \mathrm{mj}}$. & $\Delta t_{1}$ & 20 & 21 & 59 & 19 & 20 & 61 & 20 & 19 & 61 \\
\hline & $\Delta t_{2}$ & 23 & 24 & 53 & 19 & 20 & 61 & 20 & 18 & 62 \\
\hline & $\Delta t_{3}$ & 22 & 24 & 54 & 18 & 20 & 62 & 20 & 18 & 62 \\
\hline \multirow{3}{*}{$24 \mathrm{mj}}$. & $\Delta t_{1}$ & 23 & 21 & 56 & 22 & 20 & 58 & 24 & 19 & 57 \\
\hline & $\Delta t_{2}$ & 26 & 24 & 50 & 22 & 20 & 58 & 24 & 18 & 58 \\
\hline & $\Delta t_{3}$ & 25 & 24 & 51 & 21 & 20 & 59 & 25 & 18 & 57 \\
\hline \multirow{3}{*}{3 god. } & $\Delta t_{1}$ & 23 & 20 & 57 & 22 & 19 & 59 & 24 & 18 & 58 \\
\hline & $\Delta t_{2}$ & 25 & 23 & 52 & 22 & 19 & 59 & 24 & 17 & 59 \\
\hline & $\Delta t_{3}$ & 24 & 23 & 53 & 21 & 19 & 60 & 25 & 17 & 58 \\
\hline \multirow{3}{*}{8 god. } & $\Delta t_{1}$ & 18 & 16 & 66 & 17 & 15 & 68 & 19 & 14 & 67 \\
\hline & $\Delta t_{2}$ & 20 & 20 & 63 & 17 & 15 & 68 & 19 & 14 & 67 \\
\hline & $\Delta t_{3}$ & 18 & 18 & 64 & 16 & 14 & 70 & 20 & 14 & 66 \\
\hline \multirow{3}{*}{14 god. } & $\Delta t_{1}$ & 16 & 19 & 65 & 16 & 18 & 66 & 17 & 18 & 65 \\
\hline & $\Delta t_{2}$ & 19 & 21 & 60 & 15 & 19 & 66 & 17 & 17 & 66 \\
\hline & $\Delta t_{3}$ & 18 & 21 & 60 & 14 & 18 & 68 & 18 & 17 & 65 \\
\hline \multirow{3}{*}{21 god. } & $\Delta t_{1}$ & 13 & 21 & 66 & 12 & 20 & 68 & 13 & 20 & 67 \\
\hline & $\Delta t_{2}$ & 17 & 23 & 60 & 13 & 20 & 67 & 12 & 19 & 69 \\
\hline & $\Delta t_{3}$ & 15 & 23 & 62 & 12 & 19 & 69 & 12 & 20 & 68 \\
\hline
\end{tabular}


je regionalne kumulativne doze $\left(C D^{R}\right)$ kao postotak $C D_{\text {Tot }}$ i kao funkciju starosti izložene osobe. $\mathrm{CD}_{\text {Tot }}$ (čestice/kg bw) ukazuje na "teorijski" unos štetnih tvari u slučaju izloženosti pasivnom pušenju.

Razmotrena su tri vremenska intervala $\mathrm{u}$ trajanju od $1 \mathrm{~h}$ $\left(\Delta t_{1}\right) 2 \mathrm{~h}\left(\Delta t_{2}\right)$ i $3 \mathrm{~h}\left(\Delta t_{3}\right)$ za svaki uređaj za pušenje u svrhu procjene doze koju pojedinac primi boravkom $u$ istoj prostoriji nakon gašenja izvora dima. Za sve proučavane uređaje za pušenje najveći postotak čestica bio je deponiran u alveolarnoj regiji, što može inducirati alveolarnu upalu. Za konvencionalne cigarete procijenjene su veće doze nego za e-cigarete (ENDS) ili IQOS. Pasivnim pušenjem konvencionalnih cigareta, $20 \%$ i $62 \% \mathrm{CD}_{\text {Tot }}$ deponira se u glavi i alveolarnoj regiji kod 3-mjesečnog djeteta. Kod 21 -godišnjeg ispitanika postotak je bio $13 \%$ i $68 \%$. Može se zaključiti da dolazi do filtriranja većeg postotka dima u području glave kod dojenčadi i djece nego kod odraslih. Stoviše, od $60 \%$ do $80 \%$ čestica deponiranih u predjelu glave 3-mjesečnog djeteta bilo je manje od 100 nm i moglo se prenijeti u mozak. ${ }^{45} \mathrm{Za}$ sve tri serije pušenja procijenjene doze apsorpcije dima u tijelu su za IQOS bile od $50 \%$ do $110 \%$ veće za nego za e-cigarete. Razlog tomu može biti što do emisije aerosola iz e-cigarete dolazi samo kada se puši. Nasuprot tome, da bi došlo do emisije bočnog strujanja dima iz IQOS-a, dovoljno ga je samo aktivirati. Uz iznimku ENDS-a, doze aerosola povećavale su se od jedne do druge pušačke serije, jer vremenski interval od $1 \mathrm{~h}$ od početka serije pušenja nije bio dovoljan da omogući potpuno smanjenje koncentracije aerosola. Za sve analizirane uređaje za pušenje $C D^{R}$ povećale su se sa smanjenjem dobi. Točnije, ista serija pušenja, bez obzira na rabljeni uređaj, pokazala je mnogo veći rizik za pasivno izloženo dijete nego za odraslu osobu. Osobito, izloženost pasivnom pušenju tijekom djetinjstva povezana je s akutnim štetnim učincima na zdravlje, uključujući infekcije dišnog sustava, astmu i druge poremećaje dišnog sustava, te dugotrajne bolesti kardiovaskularnih i plućnih sustava.

\section{Zaključak}

Dosadašnja istraživanja pokazala su kako alternativni oblici cigareta, ENDS i HNBT uređaji, emitiraju znatno manje količine lebdećih čestica svih dimenzija i štetnih tvari u odnosu na konvencionalne cigarete. U mnogim zemljama upotreba ENDS uređaja u zatvorenim prostorijama još uvijek nije zabranjena iako brojna istraživanja ukazuju na negativne učinke redovite pasivne izloženosti parama ENDS-a. Pušenje bi također trebalo izbjegavati na privat- nim mjestima zbog sporog raspadanja lebdećih čestica, što se posebno odnosi na konvencionalne cigarete. Dakle, čak i ako pojedinac puši sam u zatvorenom okruženju, okruženje ostaje onečišćeno i doprinosi izloženosti drugih koji žive s pušačem. To je posebno važno za dojenčad i djecu, koja su podložnija štetnim učincima od odraslih. Bez obzira na to što su na tržištu dostupne cigarete s različitim karakteristikama, na temelju dosadašnjih istraživanja može se zaključiti kako su sve, u određenom mjerilu, štetne za ljudsko zdravlje. Također, potrebno je naglasiti kako su ENDS i HNBT uređaji novijeg datuma te da je potrebno provoditi još daljnja istraživanja kako bi se što bolje pojasnio njihov učinak na zdravlje čovjeka kao i ekosustav.

\section{Popis kratica List of abbreviations}

$$
\begin{aligned}
\text { BAT } & \text { - British American Tobacco } \\
\text { CD }^{R} & \text { - regionalna kumulativna doza } \\
& \text { - regional cumulative dose } \\
\text { CD }_{\text {Tot }} & \text { - ukupna kumulativna doza } \\
& \text { - total cumulative dose } \\
\text { DNA } & \text { - deoksiribonukleinska kiselina } \\
& \text { - deoxyribonucleic acid } \\
\text { ENDS } & \text { - električna cigareta tzv. e-cigareta } \\
& \text { - electrical nicotine delivery system } \\
\text { FDA } & \text { - Američka agencija za hranu i lijekove } \\
& \text { - Food and Drug Administration } \\
\text { FIRS } & \text { - Forum of International Respiratory Societies } \\
\text { GRAS } & \text { - Certifikat sigurnosti za upotrebu } \\
& \text { - Generally Recognized as Safe } \\
\text { HNBT } & \text { - heat-not-burn tobacco } \\
\text { IARC } & \text { - Međunarodna agencija za istraživanje raka } \\
& \text { - International Agency for Research on Cancer } \\
\text { IQOS } & \text { - I-Quit-Ordinary-Smoking } \\
\text { JT } & \text { - Japan Tobacco } \\
\text { PAH } & \text { - policiklički aromatski ugljikovodici } \\
& \text { - polycyclic aromatic hydrocarbons } \\
\text { PM } & \text { - lebdeće čestice } \\
& \text { - particulate matter } \\
\text { PMI } & \text { - Philip Morris International } \\
\text { THS } & \text { - dim treće ruke } \\
& \text { - thirdhand smoke } \\
\text { WHO } & \text { - Svjetska zdravstvena organizacija } \\
&
\end{aligned}
$$




\section{Literatura \\ References}

1. I. Rojnić Palavra, I. Pejnović Franelić, S. Musić Milanović, K. Puljić, Pasivno pušenje - aktivni ubojica, Liječ. Vjesn. 135 (2013) 326-329.

2. I. Ceronja, Zašto ograničiti uporabu duhanskih proizvoda?, Liječ. Vjesn. 135 (2013) 104-109.

3. H. W. Lee, S. H. Park, M. W. Weng, H. T. Wang, W. C. Huang, H. Lepor,W. R. Wu, L. C. Chen, M. S. Tang, E-cigarette smoke damages DNA and reduces repair activity in mouse lung, heart, and bladder as well as in human lung and bladder cells, Proc. Natl. Acad. Sci. USA 115 (7) (2018) 1560-1569, doi: https://doi.org/10.1073/pnas.1718185115.

4. A. A. Ruprecht, C. D. Marco, A. Saffari, P. Pozzi, R. Mazza, C. Verinese, G. Angellotti, E. Munarini, A. C. Ogliari, D. Westerdahl, S. Hasheminassad, M. M. Shafer, J. J. Schauer, J. Repace, C. Sioutas, R. Boffi, Environmental pollution and emission factors of electronic cigarettes, heat-not-burn tobacco products, and conventional cigarettes, Aerosol Sci. Tech. 51 (6) (2017) 674-684, doi: https://doi.org/10.1080/02786826.20 17.1300231 .

5. V. Kauneliene, M. Meišutovič Akhtarieva, D. Martuzevičius, A review of the impacts of tobacco heating system on indoor air quality versus conventional pollution sources, Chemosphere 206 (2018) 568-578, doi: https://doi. org/10.1016/j.chemosphere.2018.05.039.

6. G. Li, S. Saad, B. G. Oliver, H. Chen, Heat or Burn? Impacts of Intrauterine Tobacco Smoke and E-Cigarette Vapor Exposure on the Offspring's Health Outcome, Toxics 6 (2018) 1-21, doi: https://doi.org/10.3390/toxics6030043.

7. J. Mackay, J. M. Samet, Tobacco, Smoking, and Nicotine, Biomedical Sciences, Reference Module in Biomedical Sciences (3 ${ }^{\text {rd }}$ Ed.) (2014) 1-15, doi: https://doi.org/10.1016/ B978-0-12-801238-3.00169-0.

8. S. Das, J. J. Prochaska, Tobacco, Nicotine, Health, and Mental Health, Encyclopedia of Mental Health ( $2^{\text {nd }}$ Ed.) (2016) 300-313, doi: https://doi.org/10.1016/B978-0-12-3970459.00144-0.

9. S. Salvi, Tobacco smoking and environmental risk factors for chronic obstructive pulmonary disease, Clin. Chest. Med. 35 (2014) 17-27, doi: https://doi.org/10.1016/j. ccm.2013.09.011.

10. A. Jebet, J. K. Kibet, T. Kinyanjui, V. O. Nyamori, Environmental inhalants from tobacco burning: Tar and particulate emissions, Sci. African 1 (2018) 4-11, doi: https://doi. org/10.1016/j.sciaf.2018.e00004.

11. C. De Marco, A. A. Ruprecht, P. Pozzi, E. Munarini, A. C. Ogliari, R. Mazza, R. Boffi, Particulate matters from diesel heavy duty trucks exhaust versus cigarettes emissions: a new educational antismoking instrument, Multidiscip. Resp. Med. 11 (2) (2016) 1-5, doi: https://doi.org/10.1186/ s40248-016-0042-7.

12. S. Popović-Grle, Alergijske bolesti i pušenje, Acta. Med. Croatica 65 (2011) 141-146.

13. Y. Motooka, T. Matsui, R. M. Slaton, R. Umetsu, A. Fukuda, M. Naganuma, S. Hasegawa, S. Sasaoka, H. Hatahira, K. Iguchi, M. Nakamura, Adverse events of smoking cessation treatments (nicotine replacement therapy and non-nicotine prescription medication) and electronic cigarettes in the Food and Drug Administration Adverse Event Reporting System, 2004-2016, SAGE Open Med. 6 (2018) 1-1, doi: https:// doi.org/10.1177/2050312118777953.

14. A. Al-Bashaireh, L. G. Haddad, M. Weaver. D. Lynch Kelly, $X$. Chengguo, S. Yoon, The Effect of Tobacco Smoking on Musculoskeletal Health: A Systematic Review, Int. J. Envi- ron. Res. Public Health 2018 (2018) 1-107, doi: https://doi. org/10.1155/2018/4184190.

15. J. L. Fetterman, M. J. Sammy, S. W. Ballinger, Mitochondrial toxicity of tobacco smoke and air pollution, Toxicol. 391 (2017) 18-33, doi: https://doi.org/10.1016/j. tox.2017.08.002.

16. S. I. DiGiacomo, M. A. Jazayeri, R. Barua, J. A. Ambrose, Environmental Tobacco Smoke and Cardiovascular Disease, Int. J. Env. Res. Pub. He. 16 (2019) 1-12, doi: https://doi. org/10.3390/ijerph16010096.

17. M. P. Martinasek, A. Bowersock, C. W. Wheldon, Patterns, Perception and Behavior of Electronic Nicotine Delivery Systems Use and Multiple Product Use Among Young Adults, Resp. Care 63 (2018) 913-919, doi: https://doi.org/10.4187/ respcare.06001.

18. D. Poppendieck, S. Khurshid, S. Emmerich, Measuring Airborne Emissions from Cigarette Butts: Literature Review and Experimental Plan, NISTIR 8147 (2016) 1-50, doi: https:// doi.org/10.6028/NIST.IR.8147.

19. S. G. Matta, D. J. Balfour, N. L. Benowitz, R. T. Boyd, J. J. Buccafusco, A. R. Caggiula, C. R. Craig, A. C. Collins, M. I. Damaj, E. C. Donny, P. S. Gardiner, S. R. Grady, U. Heberlein, S. S. Leonard, E. D. Levin, R. J. Lukas, A. Markou, M. J. Marks, S. E. McCallum, N. Parameswaran, K. A. Perkins, M. R. Picciotto, M. Quik, J. E. Rose, A. Rothenfluh, W. R. Schafer, I. P. Stolerman, R. F. Tyndale, J. M. Wehner, J. M., Zirger, Guidelines on nicotine dose selection for in vivo research, Psychopharmacol. 190 (2007) 269-319, doi: https://doi.org/10.1007/ s00213-006-0441-0.

20. M. Unger, D. W. Unger, E-cigarettes/electronic nicotine delivery system: a word of caution on health and new product development, J. Thorac. Dis. 10 (2018) 2588-2592, doi: https://doi.org/10.21037/jtd.2018.07.99.

21. N. L. Benowitz, Nicotine Addiction, New Engl. J. Med. 362 (24) (2010) 2295-2303, doi: https://doi.org/10.1056/NEJMra0809890.

22. A. Pisera-Fuster, L. Rocco, M. P. Faillace, R. Bernabeu, Sensitization - dependent nicotine place preference in the adult zebrafish, Prog. Neuro - Psychoph. 92 (2019) 457-469, doi: https://doi.org/10.1016/j.pnpbp.2019.02.018.

23. M. R. Zarrindast, F. Khakpai, The modulatory role of nicotine on cognitive and non-cognitive functions, Brain Res. 1710 (2019) 92-101, doi: https://doi.org/10.1016/j.brainres.2018.12.002.

24. A. Mishra, P. Chaturvedi, S. Datta, S. Sinukumar, P. Joshi, A. Garg, Harmful effects of nicotine, Indian. J. Med. Paediatr. Oncol. 36 (1) (2015) 24-31, doi: https://doi. org/10.4103/0971-5851.151771.

25. V. Žlender, Apoptoza - programirana smrt stanice, Arh. Hig. Rada. Toksikol. 54 (2003) 267-274.

26. O. J. Lo, M. C. Schabel, V. H. J. Roberts, T. K. Morgan, J. P. Rasanen, C. D. Kroenke, S. R. Shoemaker, E. R. Spindel, A. E. Frias, Vitamin $C$ supplementation ameliorates the adverse effects of nicotine on placental hemodynamics and histology in nonhuman primates, Am. J. Obstet. Gynecol. 212 (3) (2014) 1-8, doi: https://doi.org/10.1016/j.ajog.2014.12.042.

27. G. Kaur, T. Muthumalage, I. Rahman, Mechanisms of toxicity and biomarkers of flavoring and flavor enhancing chemicals in emerging tobacco and non-tobacco products, Toxicol. Lett. 288 (2018) 143-155, doi: https://doi.org/10.1016/j. toxlet.2018.02.025.

28. G. Li, S. Saad, B. G. Oliver, H. Chen, Heat or Burn? Impacts of Intrauterine Tobacco Smoke and E-Cigarette Vapor Exposure on the Offspring's Health Outcome, Toxics 6 (3) (2018) 1-21, doi: https://doi.org/10.3390/toxics6030043. 
29. M. Korfei, The underestimated danger of E cigarettes -also in the absence of nicotine, Respir. Res. 19 (2018) 1-4, doi: https://doi.org/10.1186/s12931-018-0870-4.

30. M. Bansal, M. Sharma, C. Bullen, D. Svirskis, A Stability Indicating HPLC Method to Determine Actual Content and Stability of Nicotine within Electronic Cigarette Liquids, Int. J. Environ. Res. Pub. He. 15 (2018) 1-11, doi: https://doi. org/10.3390/ijerph15081737.

31. S. Vreeke, D. H. Peyton, R. M. Strongin, Triacetin Enhances Levels of Acrolein, Formaldehyde Hemiacetals, and Acetaldehyde in Electronic Cigarette Aerosols, ACS Omega 3 (7) (2018) 7165-7170, doi: https://doi.org/10.1021/acsomega.8b00842.

32. M. D. Blank, A. B. Breland, C. O. Cobb, T. Spindle, C. Ramoa, T. Eissenberg, Clinical Laboratory Evaluation of Electronic Cigarettes: Methodological Challenges, Tobacco Regulatory Science 2 (4) (2016) 426-439, doi: https://doi. org/10.18001/TRS.2.4.12.

33. R. Z. Behar, W. Luo, K. J. McWhirter, J. F. Pankow, P. Talbot, Analytical and toxicological evaluation of flavor chemicals in electronic cigarette refill fluids, Sci. Rep.-UK 8 (2018) 1-11, doi: https://doi.org/10.1038/s41598-018-25575-6.

34. B. Phillips, B. Titz, U. Kogel, D. Sharma, P. Leroy, Y. Xiang, G. Vuillaume, S. Lebrun, D. Sciuscio, J. Ho, C. Nury, E. Guedj, A. Elamin, M. Esposito, S. Krishnan, W. K. Schlage,E. Veljkovic, N. V. Ivanov, F. Martin, M. C. Peitsch, J. Hoeng, P. Vanscheeuwijck, Toxicity of the main electronic cigarette components, propylene glycol, glycerin, and nicotine, in Sprague-Dawley rats in a 90-day OECD inhalation study complemented by molecular endpoints, Food. Chem. Toxicol. 109 (2017) 315332, doi: https://doi.org/10.1016/j.fct.2017.09.001.

35. K. Torikaiu, Y. Uwano, T. Nakamori, W. Tarora, H. Takahashi, Study on tobacco components involved in the pyrolytic generation of selected smoke constituents, Food Chem. Toxicol. 43 (4) (2005) 559-568, doi: https://doi.org/10.1016/j. fct.2004.12.011.

36. R. R. Baker, Smoke generation inside a burning cigarette: modifying combustion to develop cigarettes that may be less hazardous to health, Prog. Energy Combust. Sci. 32 (4) (2006) 373-385, doi: https://doi.org/10.1016/j.pecs.2006.01.001.

37. J. Yoshida, The Rise of Heat - Not Burn Tobacco in Japan: A "Hot" Issue for Tobacco Control, J. Thorac. Oncol. 13 (10)
(2018) 271, doi: https://doi.org/10.1016/j.jtho.2018.08.152.

38. S. Uchiyama, M. Noguchi, N. Takagi, H. Hayashida, Y. Inaba, H. Ogura, N. Kunugita, Simple Determination of Gaseous and Particulate Compounds Generated from Heated Tobacco Products, Chem. Res. Toxicol. 31 (7) (2018) 585-593, doi: https://doi.org/10.1021/acs.chemrestox.8b00024.

39. M. R. Smith, B. Clark, F. Ludicke, J. P. Schaller, P. Vanscheeuwijck, J. Hoeng, M. C. Peitsch, Evaluation of the Tobacco Heating System 2.2. Part 1: Description of the system and the scientific assessment program, Regul. Toxicol. Pharmacol. 81 (2) (2016) 17-26, doi: https://doi.org/10.1016/j. yrtph.2016.07.006.

40. J. P. Schaller, J. P. M. Pijnenburg, A. Ajithkumar, A. R. Tricker, Evaluation of the Tobacco Heating System 2.2. Part 3: Influence of the tobacco blend on the formation of harmful and potentially harmful constituents of the Tobacco Heating System 2.2 aerosol, Regul. Toxicol. Pharmacol. 81 (2) (2016) 48-58, doi: https://doi.org/10.1016/j.yrtph.2016.10.016.

41. M. I. Mitova, P. B. Campelos, C. G. Goujon-Ginglinger, S. Maeder, N. Mottier, E. G. Rouget, M. Tharin, A. R. Tricker, Comparison of the impact of the Tobacco Heating System 2.2 and a cigarette on indoor air quality, Regul. Toxicol. Pharmacol. 80 (2016) 91-101, doi: https://doi.org/10.1016/j. yrtph.2016.06.005.

42. URL: https://www.pmi.com/smoke-free-products/ iqos-our-tobacco-heating-system (6. 4. 2019.).

43. W. Schober, L. Fembacher, A. Frenzen, H. Fromme, Passive exposure to pollutants from conventional cigarettes and new electronic smoking devices (IQOS, e-cigarette) in passenger cars, Int. J. Hyg. Environ. Health. 222 (3) (2019) 486-493, doi: https://doi.org/10.1016/j.ijheh.2019.01.003.

44. S. Uchiyama, M. Noguchi, N. Takagi, H. Hayashida, Y. Inaba, H. Ogura, N. Kunugita, Simple Determination of Gaseous and Particulate Compounds Generated from Heated Tobacco Products, Chem. Res. Toxicol. 31 (7) (2018) 585-593, doi: https://doi.org/10.1021/acs.chemrestox.8b00024.

45. C. Protano, M. Manigrasso, M. Avino, M. Vitali, Second-hand smoke generated by combustion and electronic smoking devices used in real scenarios: Ultrafine particle pollution and age-related dose assessment, Environ. Int. 107 (2017) 190195, doi: https://doi.org/ 10.1016/j.envint.2017.07.014.

\section{SUMMARY}

\section{Conventional Cigarettes vs. Alternative Devices - Impact on Human Health and Ecosystem}

Dajana Kučić Grgić, ${ }^{* *}$ Iva Bićanić, Nina Čavarović, ${ }^{a}$ Petra Pohanić, and Vesna Ocelić Bulatovićb

Tobacco smoke is the leading preventable cause of death worldwide, and smoking has become a less desirable habit in many social segments. Therefore, during the last decade, the tobacco industry has developed some alternatives - ENDS and HNBT products, in order to offer a less harmful option for consumers. E-cigarette manufacturers are referred to the GRAS declaration which refers exclusively to ingestion, while the inhalation of the aerosol itself, which occurs in both of these products, is harmful. E-cigarettes create an aerosol by heating e-liquid, and HNBT devices are based on heating the coated tobacco leaves thus producing harmful compounds although at considerably lower concentrations than conventional cigarettes.

\section{Keywords}

Tobacco smoke, ENDS, HNBT, aerosol, adverse impact on health and environment

a Faculty of Chemical Engineering and

Technology, University of Zagreb, Croatia

b Faculty of Metallurgy, University of Zagreb,

Croatia
Review

Received May 15, 2019

Accepted June 8, 2019 